\title{
Studies on 2,4-D Dimethylamine 50\% SL to Control Weeds in Wheat
}

\author{
Arindam Kundu ${ }^{1 *}$, Champak Kumar Kundu' ${ }^{1}$, Himangshu Das ${ }^{2}$, \\ Kanu Murmu ${ }^{1}$ and Kalyan Jana ${ }^{1}$ \\ ${ }^{1}$ Department of Agronomy, Faculty of Agriculture, Bidhan Chandra Krishi Viswavidyalaya, \\ Mohanpur, Nadia, West Bengal - 741252, India \\ ${ }^{2}$ Gramin Krishi Mausam Sewa, Malkangiri, Orissa University of Agriculture and Technology, \\ Odisha-764045, India \\ *Corresponding author
}

\begin{tabular}{|l|}
\hline K e y w o r d s \\
2,4-D dimethylamine \\
50\% SL, Weed \\
management, Grain yield, \\
Phytotoxicity
\end{tabular}

\section{Introduction}

Wheat (Triticum aestivum L.) is the king of the cereals and provides more nourishment (rich in carbohydrates). To fulfil the world

\section{A B S T R A C T}

A field experiment was conducted at regional research station of Bidhan Chandra Krishi Viswavidyalaya, Chakdaha, Nadia, West Bengal during Rabi season, 2012-13 to find out the various effect for controlling weeds in Rabi wheat (PBW- 343) grown with recommended package of practices by the application of 2,4-D Dimethylamine 50\% SL. The experiment was laid out in Randomized Block Design, comprising of nine treatments. Treatments were as follows: $\mathrm{T}_{1}-2,4-\mathrm{D}$ amine $50 \% \mathrm{SL}$ (Nufarm) @ $0.25 \mathrm{~kg}$ a.i. ha ${ }^{-1}, \mathrm{~T}_{2}$ 2,4-D amine 50\% SL (Nufarm) @ $0.50 \mathrm{~kg}$ a.i. ha ${ }^{-1}, \mathrm{~T}_{3}-2,4-\mathrm{D}$ amine 50\% SL (Nufarm) @ $0.75 \mathrm{~kg}$ a.i. ha ${ }^{-1}, \mathrm{~T}_{4}-2$,4-D amine 50\% SL (Nufarm) @ $1.00 \mathrm{~kg}$ a.i. ha ${ }^{-1}, \mathrm{~T}_{5}-2$ 2,4-D amine $58 \%$ SL (Commercial) @ $0.50 \mathrm{~kg}$ a.i. ha ${ }^{-1}, \mathrm{~T}_{6}$ - Metsulfuron methyl 20\% WP @ $0.004 \mathrm{~kg}$ a.i. ha ${ }^{-1}, \mathrm{~T}_{7}$ - Hand Weeding at 20 DAS \& 40 DAS, $\mathrm{T}_{8}-$ Unweeded control treatments and $\mathrm{T}_{9}$ - 2,4-D amine 50\% SL (Nufarm) @ $2.00 \mathrm{~kg}$ a.i. ha ${ }^{-1}$ and replicated thrice. In between aforesaid treatments, $\mathrm{T}_{9}-2,4-\mathrm{D}$ amine 50\% SL (Nufarm) @ $2.00 \mathrm{~kg}$ a.i. ha ${ }^{-1}$ was included only for phytotoxicity observation. Phalaris minor, Cynodon dactylon, Avena fatua, Chenopodium album, Cirsium arvense, Fumaria parviflora, Anagallis arvensis, Cyperus rotundus and Cyperus iria were the dominant weed species. Among the weed control methods 2,4-D amine 50\% SL (Nufarm) @ $1.0 \mathrm{~kg}$ a.i. $\mathrm{ha}^{-1}\left(\mathrm{~T}_{4}\right)(40.00,16.73$ and $34.34 \%$ respectively) and 2,4-D amine 50\% SL(Nufarm)@0.75 kg a.i. ha ${ }^{-1}\left(\mathrm{~T}_{3}\right)(40.00,15.82$ and $32.06 \%$ respectively) recorded the higher weed control efficiency after hand weeding twice at 20, 40 and 60 DAS. Among the herbicide treatments, maximum grain yield and lowest weed index were recorded under 2,4-D amine 50\% SL (Nufarm) @ $1.00 \mathrm{~kg}$ a.i. ha ${ }^{-1}$ $\left(\mathrm{T}_{4}\right)\left(1.80 \mathrm{t} \mathrm{ha}^{-1}\right.$ and $2.70 \%$ respectively) plot. The herbicide $2,4-\mathrm{D}$ amine $50 \%$ SL tested at different doses and the tested new formulation is safe to the wheat crop. food demand, wheat ranks top mostly grown and consumed in almost whole of the world (Noorka et al., 2013). It belongs to family Poaceae, is a worldwide-cultivated important cereal crop. A $17 \%$ world's cropped area is 
under wheat cultivation which together adds $35 \%$ of the staple food and $20 \%$ of the calories (Chhokar et al., 2006). It is the cheapest source supplying $72 \%$ of calories and protein in the average diet (Heyne, 1987 and Noorka et al., 2012).

In India, the larger part of the population depends upon wheat for food and its enhanced production is indispensable for food security. The wheat production in India, has increased from 11.0 Million Tonnes (MT) during 196061 to 93.50 MT during 2015-16. It covers an area of $30.23 \mathrm{M}$ ha with an average yield of $3093 \mathrm{kgha}^{-1}$ and in West Bengal, it is grown in $0.34 \mathrm{M}$ ha area with the production of $0.96 \mathrm{MT}$ (Agri. Stat. at a glance, 2016). It is true that wheat production may be increased by either increasing the area under wheat crop or maximizing yield per unit area but this yield is gradually decreasing day by day due to different factors in which weed is one of them. Weeds cause more loses to agriculture than all pests (Gella et al., 2013). There are innumerable reports on negative effects of weeds on crop plants (Javaid et al., 2007) thus cause huge yield losses (Rathore et al., 2014). Unchecked weed growth reduces crop yield up to $57 \%$ (Singh et al., 1997). Weed infestation may reduce yield by 30-50\% (Pandey et al., 1997), 45.5 to $63.9 \%$ (Reddy and Reddi, 2002), 40.3\% (Rajeev et al., 2012), 30\% (Zand et al., 2007), 25.35\% (Dangwal et al., 2010) in wheat while reduced up to $92 \%$ by competition from ryegrass (Dickson et al., 2011), $17.62 \%$ due to wild oat (Marwat et al., 2011).

Wheat yield severely reduced due to broadspectrum weed flora in different areas of India. Number of weed species in wheat field varied country to country and up to 90 weed species have been reported in India (Rao, 2000), 73 in Bangladesh (Begum et al., 2003), 45 in Pakistan (Qureshi and Bhatti, 2001) and 33 in Iran (Buczek et al., 2011). Moreover, weeds serve as alternate hosts to insects, nematodes and pathogenic fungi such as common broad leaved weeds for Fusarium (Postic et al., 2012), wild grasses and grassy weeds for wheat streak mosaic virus and its vector and wheat curl mite (Ito et al., 2012).

Weeds are one of the major constraints of wheat production and weed control is the key factor in increasing yield (Lopez-Granados, 2011; Shehzad et al., 2012).Weed control has been observed as one of the most important practice in crop production because good weed control will ensure maximum yield and high quality of farm produce (Njoroge, 1999). Weeds can be controlled by different approaches such as manual methods, mechanical methods, allelopathic weed control, biological weed control and chemical control. Currently, chemical weed control has emerged as an effective tool for weed management because it is approachable, less time consuming as well as economical (Duke and Lydon, 1987; Jarwar et al., 1999; Baghestani et al., 2007). This method involves the use of chemicals commonly known as Herbicides or Weedicides. 2,4-D is an exclusively broad-leaved killer herbicide and has some sedge (Cyperusrotundus/esculentus) killing activity (Das, 2013). 2,4-D are generally formulated as inorganic or amine salts, or as esters (Wilson et al., 1997). 2, 4-D amine salts are usually in liquid form. They have balanced solubility in lipoid and water. The persistence in soil is greater and more absorption/uptake by plant through roots (Das, 2013). Metsulfuron and 2,4-D herbicides have been used for control of weeds in wheat crop. Because this combination control of both type of weed flora i.e. narrow and broad leaved (Singh et al., 2013).

Keeping in view the losses due to weed infestation and high efficiency of weed control by chemical method, the present study was undertaken to test the Performance of 2, 4-D 
Dimethylamine $50 \%$ SL to control of weeds and also the ability of increasing yield in wheat.

\section{Materials and Methods}

\section{Experimental location, topography and soil type}

A field experiment was conducted at Regional Research Station $\left(28^{0} 5.3^{\prime} \mathrm{N}\right.$ latitude and $83^{\circ}$ $5.3^{\prime}$ E longitude and the election of $9.75 \mathrm{~m}$ above the mean sea level), BCKV, Chakdaha, West Bengal to study the effect of 2,4-D dimethylamine $50 \%$ SL to control of weeds in Wheat during the Rabi season, 2012-2013 in the sub-humid and sub-tropical condition of West Bengal. Topography of the land was referred as medium land situation and the soil of the experiment field was sandy loam with moderate $\mathrm{pH}$ level (6.8). The available $\mathrm{N}$ status of the soil was low whereas available $\mathrm{P}$ and $\mathrm{K}$ contents were in medium range with high base saturation and CEC (Cation Exchange Capacity).

\section{Experimental details}

The experiment was laid out in Randomized Block Design, comprising of nine treatments. Treatments were as follows: $\mathrm{T}_{1}-2,4-\mathrm{D}$ amine $50 \%$ SL (Nufarm) @ $0.25 \mathrm{~kg}$ a.i. ha ${ }^{-1}, \mathrm{~T}_{2}-2,4-$ D amine 50\% SL (Nufarm) @ $0.50 \mathrm{~kg}$ a.i. ha ${ }^{-}$ $1, \mathrm{~T}_{3}-2,4-\mathrm{D}$ amine 50\% SL (Nufarm) @ 0.75 $\mathrm{kg}$ a.i. $\mathrm{ha}^{-1}, \mathrm{~T}_{4}-2,4-\mathrm{D}$ amine $50 \% \mathrm{SL}$ (Nufarm) @ $1.00 \mathrm{~kg}$ a.i. ha ${ }^{-1}, \mathrm{~T}_{5}$ - 2,4-D amine $58 \%$ SL (Commercial) @ $0.50 \mathrm{~kg}$ a.i. ha ${ }^{-1}, \mathrm{~T}_{6}$ Metsulfuron methyl 20\% WP @ $0.004 \mathrm{~kg}$ a.i. $\mathrm{ha}^{-1}, \mathrm{~T}_{7}$ - Hand Weeding at 20 DAS \& 40 DAS, $\mathrm{T}_{8}-$ Unweeded control treatments and $\mathrm{T}_{9}$ - 2,4-D amine 50\% SL (Nufarm) @ $2.00 \mathrm{~kg}$ a.i. $\mathrm{ha}^{-1}$ and replicated thrice. In between aforesaid treatments, $\mathrm{T}_{9}-2,4-\mathrm{D}$ amine $50 \% \mathrm{SL}$ (Nufarm)@ $2.00 \mathrm{~kg}$ a.i. ha ${ }^{-1}$ was included only for phytotoxicity observation. Each plots for this experiment was divided in $5 \mathrm{~m} \times 4 \mathrm{~m}$ area and the wheat variety PBW-343was planted at $20 \mathrm{~cm}$ spacing between rows using seed rate $100 \mathrm{kgha}^{-1}$ on $7^{\text {th }}$ December, 2012. Herbicidal treatments were applied as pre emergence (Metsulfuron methyl 20\% WP) on $10^{\text {th }}$ December, 2012and in case of post emergence (2,4-D amine 50\% SLand 2,4-D amine $58 \%$ SL) on $10^{\text {th }}$ January, 2013 as their respective doses as per treatments. Spraying was done with the help of knapsack sprayer fitted with a flat fan nozzle with the spray volume of water $500 \mathrm{lha}^{-1}$.The crop was managed as per the standard package of practices. All the recommended plant protection measures were undertaken during the course of investigation.

\section{Data recording}

Data on weeds were recorded at 20, 40 and 60 Days After Sowing (DAS). An area of $0.25 \mathrm{~m}^{2}$ was selected randomly at two spots by throwing a quadrat of $0.5 \times 0.5 \mathrm{~m}$, weed species were counted from that area and density was expressed in number $\mathrm{m}^{-2}$. The collected weeds were first sun-dried and then kept in an electric oven at $75^{\circ} \mathrm{C}$ for $72 \mathrm{~h}$ for the measurement of dry weight or biomass and was expressed as $\mathrm{g} \mathrm{m}^{-2}$. Weed control efficiency was calculated based on the weed biomass respectively. The WCE efficiency was calculated as:

W. C. E $(\%)=\frac{\text { Weed dry matter in control plot- weed dry matter in treated plot }}{\text { Weed dry matter in control plot }} \times 100$

The observation on visual crop toxicity was done on 7, 14 and 21 days after herbicide application (DAHA). The visual crop toxicity symptoms like leaf injury, vein clearing, epinasty, hyponasty, scorching and necrosis were observed.

The grain weight of wheat for above aforesaid treatments was recorded in kilogram and later expressed in tonnes per hectare $\left(\mathrm{t} \mathrm{ha}^{-1}\right)$. 
Weed index has been calculated with the formula:

$\mathrm{WI}=\frac{x-y}{x} \times 100$

Where,

$\mathbf{x}=$ weight of seed yield $\left(\mathrm{t} \mathrm{ha}^{-1}\right)$ in treatment which has highest yield

$\mathbf{y}=$ weight of seed yield $\left(\mathrm{t} \mathrm{ha}^{-1}\right)$ in treatment for which weed index is to be calculated.

\section{Statistical analysis}

The treatments were allocated randomly to different plots with the help of random number table (Fisher, 1958) and the data were analysed by ANOVA, and ranked by using the critical differences (CD) at 5\% level.

\section{Results and Discussion}

\section{Dominant weed flora}

The dominant weed flora found in the experiment plot at different stages during the crop period indicated that different types of grassy and non-grassy weeds. Among grassy weeds, predominant Phalaris minor, Cynodon dactylon, Avena fatua and among non-grassy weeds, viz. Chenopodium album, Cirsium arvense, Fumaria parviflora, Anagallis arvensis were under broadleaf weedsand in sedges, viz. Cyperus rotundus and Cyperus iria were observed. Similar type of observation was also reported by Bandyopadhyay et al., (2017).

\section{Effect of different weed control measures}

\section{Weed density}

The density of broad leaf weed, grassy weed and sedge weeds at 20,40 and 60 DAS (Days
After Sowing) has been presented in table 1 . The data on weed count has revealed that the population of broad leaf weed $(0.68,1.62$ and 2.36 no. $\mathrm{m}^{-2}$ respectively), sedge weed ( 0.46 , 0.66 and 1.60 no. $\mathrm{m}^{-2}$ respectively) and grassy weed $\left(0.13,0.54\right.$ and 0.65 no. $\mathrm{m}^{-2}$ respectively) was recorded lowest underhand weeding twice plot at 20, 40 and 60 DAS. All the weed control treatments significantly reduced all type of weeds compared to unweeded control treatment.

Among the herbicidal treatments, 2,4-D amine $50 \%$ SL (Nufarm) @ $1.00 \mathrm{~kg}$ a.i. ha ${ }^{-1}\left(\mathrm{~T}_{4}\right)$ recorded least weed population at given days' interval followed by 2,4-D amine 50\% SL (Nufarm) @ $0.75 \mathrm{~kg}$ a.i. ha ${ }^{-1}\left(\mathrm{~T}_{3}\right)$. Appraisal of the data revealed that 2,4-D amine 50\% SL (Nufarm) @ $1.00 \mathrm{~kg}$ a.i. ha ${ }^{-1}\left(\mathrm{~T}_{4}\right)$ has resulted in effective control of total weed population and has recorded least weed count $(1.67,3.65$ and 5.00no. $\mathrm{m}^{-2}$ respectively) at 20, 40 and 60 DAS and remained at par among themselves and superior to the other treatments except hand weeding twice $\left(\mathrm{T}_{7}\right)$. 2,4-D amine 50\% SL (Nufarm)@ $1.00 \mathrm{~kg}$ a.i. ha ${ }^{-1}\left(\mathrm{~T}_{4}\right)$ was statistically at par with 2,4-D amine 50\% SL (Nufarm) @ $0.75 \quad \mathrm{~kg}$ a.i. ha ${ }^{-1}\left(\mathrm{~T}_{3}\right)$ in controlling the total weed population. This result corroborated the findings of Kundu et al., 2018.

The unweeded control treatment $\left(\mathrm{T}_{8}\right)$ recorded the highest weed count at all the observations on given days' interval with the pre dominance of broadleaf weeds $(4.35,5.58$ and 8.80 no. $\mathrm{m}^{-2}$ respectively) followed by sedges (2.61, 5.09 and 4.89no. $\mathrm{m}^{-2}$ respectively) and after than grasses $\left(0.95,1.46\right.$ and 2.61 no. $\mathrm{m}^{-2}$ respectively).

The population of different type of weeds followed the same tradition in all the treatments. These results were in harmony with the findings of several workers (Kundu et al., 2017 and Bandyopadhyay et al., 2017). 
Table.1 Effect of treatments on density of various weeds (No. $\mathrm{m}^{-2}$ ) in wheat

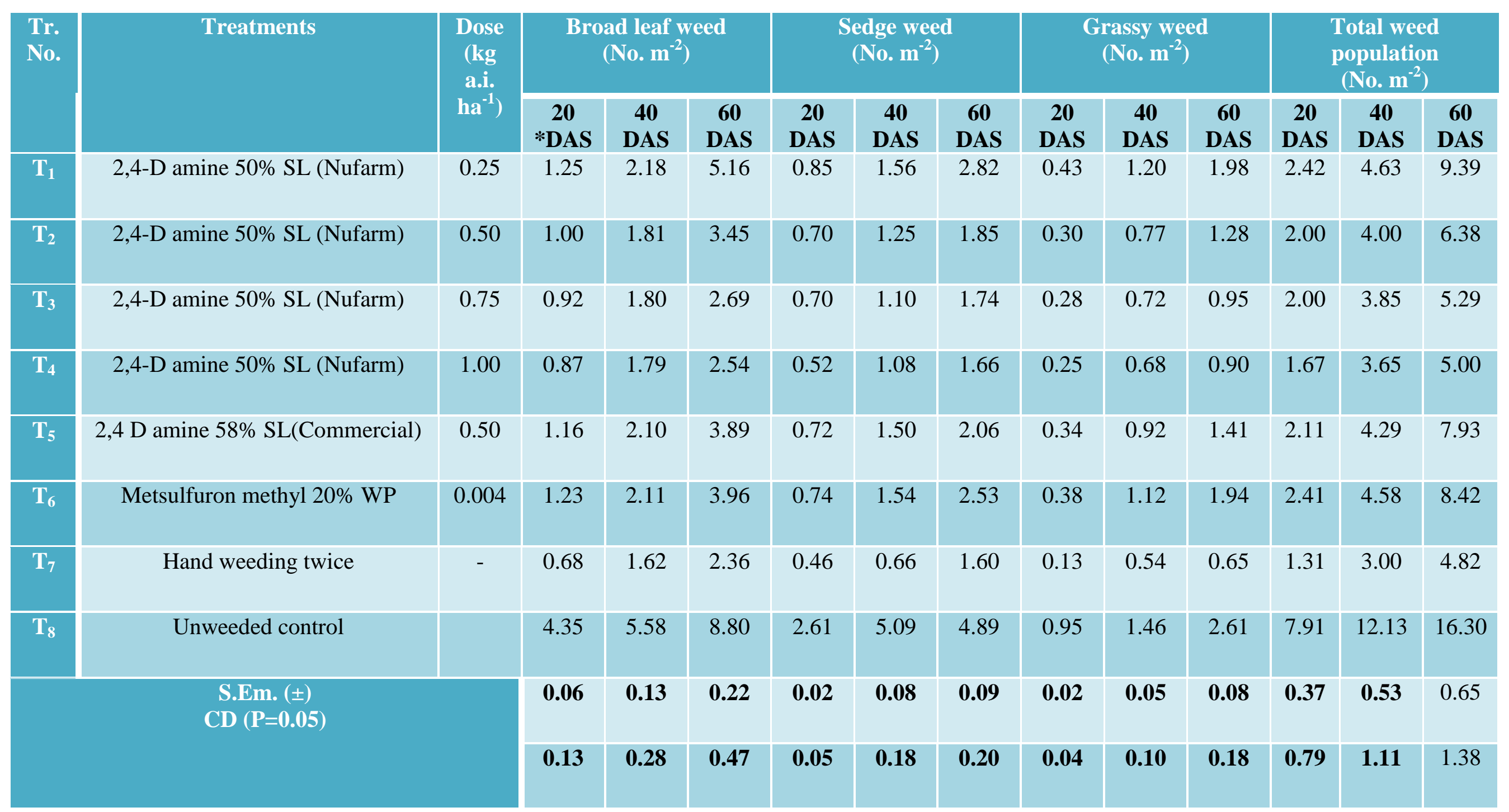

*- Days After Sowing 
Table.2 Effect of treatments on total weed dry matter accumulation and weed control efficiencyin wheat

\begin{tabular}{|c|c|c|c|c|c|c|c|c|}
\hline \multirow[t]{2}{*}{$\begin{array}{l}\text { Tr. } \\
\text { No. }\end{array}$} & \multirow[t]{2}{*}{ Treatments } & \multirow{2}{*}{$\begin{array}{c}\text { Dose } \\
(\mathrm{kg} \\
\text { a.i. } \\
\text { ha }^{-1} \text { ) }\end{array}$} & \multicolumn{3}{|c|}{$\begin{array}{l}\text { Total weed dry matter } \\
\text { accumulation }\left(\mathrm{g} \mathrm{m}^{-2}\right)\end{array}$} & \multicolumn{3}{|c|}{$\begin{array}{c}\text { Weed control } \\
\text { efficiency } \\
(\%)\end{array}$} \\
\hline & & & $\begin{array}{c}20 \\
\text { DAS }\end{array}$ & $\begin{array}{c}40 \\
\text { DAS }\end{array}$ & $\begin{array}{c}60 \\
\text { DAS }\end{array}$ & $\begin{array}{c}20 \\
\text { DAS }\end{array}$ & $\begin{array}{c}40 \\
\text { DAS }\end{array}$ & $\begin{array}{c}60 \\
\text { DAS }\end{array}$ \\
\hline $\mathbf{T}_{1}$ & 2,4-D amine 50\% SL (Nufarm) & 0.25 & 1.81 & 12.93 & 16.20 & 9.50 & 2.12 & 19.84 \\
\hline $\mathbf{T}_{2}$ & 2,4-D amine $50 \%$ SL (Nufarm) & 0.50 & 1.21 & 11.32 & 13.87 & 39.50 & 14.31 & 31.37 \\
\hline $\mathbf{T}_{\mathbf{3}}$ & 2,4-D amine $50 \%$ SL (Nufarm) & 0.75 & 1.20 & 11.12 & 13.73 & 40.00 & 15.82 & 32.06 \\
\hline $\mathbf{T}_{4}$ & 2,4-D amine $50 \%$ SL (Nufarm) & 1.00 & 1.20 & 11.00 & 13.27 & 40.00 & 16.73 & 34.34 \\
\hline $\mathbf{T}_{\mathbf{5}}$ & $2,4 \mathrm{D}$ amine $58 \% \mathrm{SL}($ Commercial $)$ & 0.50 & 1.31 & 12.00 & 14.21 & 34.50 & 9.16 & 29.69 \\
\hline $\mathrm{T}_{6}$ & Metsulfuron methyl 20\% WP & 0.004 & 1.73 & 12.78 & 14.27 & 13.50 & 3.26 & 29.39 \\
\hline $\mathbf{T}_{7}$ & Hand weeding twice & - & 0.97 & 8.47 & 11.27 & 51.50 & 35.88 & 44.24 \\
\hline $\mathbf{T}_{8}$ & Unweeded control & & 2.00 & 13.21 & 20.21 & - & - & - \\
\hline & S.Em. $( \pm)$ & & 0.07 & 0.52 & 0.65 & - & - & - \\
\hline & $\mathrm{CD}(\mathrm{P}=0.05)$ & & 0.15 & NS & 1.38 & - & - & - \\
\hline
\end{tabular}

Table.3 Effect of treatments on phytotoxicity, grain yield $\left(\mathrm{t} \mathrm{ha}^{-1}\right)$ and weed index $(\%)$ in wheat

\begin{tabular}{|c|c|}
\hline $\begin{array}{l}\text { Tr. } \\
\text { No. }\end{array}$ & Treatments \\
\hline $\mathbf{T}_{1}$ & 2,4-D amine $50 \%$ SL (Nufarm) \\
\hline $\mathbf{T}_{2}$ & 2,4-D amine $50 \%$ SL (Nufarm) \\
\hline $\mathbf{T}_{3}$ & 2,4-D amine $50 \%$ SL (Nufarm) \\
\hline $\mathbf{T}_{4}$ & 2,4-D amine $50 \%$ SL (Nufarm) \\
\hline $\mathbf{T}_{5}$ & 2,4 D amine $58 \% \mathrm{SL}($ Commercial) \\
\hline$T_{6}$ & Metsulfuron methyl 20\% WP \\
\hline $\mathrm{T}_{7}$ & Hand weeding twice \\
\hline $\mathrm{T}_{8}$ & Unweeded control \\
\hline$* * \mathbf{T}_{9}$ & 2,4-D amine $50 \%$ SL (Nufarm) \\
\hline
\end{tabular}

* - Days After Herbicide Application

**- Included only for phytotoxicity

Total weed Dry Matter Accumulation [DMA] and Weed Control Efficiency [WCE]

The dry matter production of weeds was recorded at 20,40 and 60 DAS. Significant

\begin{tabular}{c|c|c|c|c|c|}
$\begin{array}{c}\text { Dose } \\
\text { a.i. } \\
\mathbf{k g} \\
\text { ha }^{-1}\end{array}$ & $\begin{array}{c}\text { Phytotoxicity observation } \\
\text { *DAHA }\end{array}$ & $\begin{array}{c}\mathbf{1 4} \\
\text { DAHA }\end{array}$ & $\begin{array}{c}\mathbf{2 1} \\
\text { DAHA }\end{array}$ & $\begin{array}{c}\text { Grain } \\
\text { yield (t } \\
\mathbf{h a}^{-\mathbf{1}} \mathbf{( t}\end{array}$ & $\begin{array}{c}\text { Weed } \\
\text { index } \\
\mathbf{( \% )}\end{array}$ \\
\hline 0.25 & 0 & 0 & 0 & 1.35 & 27.02 \\
\hline 0.50 & 0 & 0 & 0 & 1.61 & 12.97 \\
\hline 0.75 & 0 & 0 & 0 & 1.70 & 8.10 \\
\hline 1.00 & 0 & 0 & 0 & 1.80 & 2.70 \\
\hline 0.50 & 0 & 0 & 0 & 1.52 & 17.83 \\
\hline 0.004 & 0 & 0 & 0 & 1.40 & 24.32 \\
\hline- & 0 & 0 & 0 & 1.85 & - \\
\hline & 0 & 0 & 0 & 1.30 & 29.72 \\
\hline 2.00 & 0 & 0 & 0 & - & - \\
\hline & - & - & - & $\mathbf{N S}$ & - \\
\hline & - & - & - & $\mathbf{N S}$ & - \\
\hline
\end{tabular}


and $13.27 \mathrm{gm} \mathrm{m}^{-2}$ respectively) and 2,4-D amine 50\% SL (Nufarm) @ $0.75 \mathrm{~kg}$ a.i. ha ${ }^{-1}$ $\left(\mathrm{T}_{3}\right) \quad\left(1.20, \quad 11.12\right.$ and $\left.13.73 \mathrm{gm} \mathrm{m}^{-2}\right)$ respectively. Consequent to the lower density of weeds observed in hand weeding twice $\left(\mathrm{T}_{7}\right)$ followed by 2,4-D amine 50\% SL (Nufarm) @ $1.00 \mathrm{~kg}$ a.i. $\mathrm{ha}^{-1}\left(\mathrm{~T}_{4}\right)$ and 2,4-D amine 50\% SL (Nufarm) @0.75 kg a.i. ha ${ }^{-1}\left(\mathrm{~T}_{3}\right)$, The weed dry weight was recorded least in the aforesaid treatments.

The weed dry weight in the recommended treatments remained at par among themselves and also recorded significantly superior to the other treatments at all the stages especially than the standard treatments viz., 2,4-D amine $58 \%$ SL (Commercial) @ $0.50 \mathrm{~kg} \mathrm{a.i.} \mathrm{ha}{ }^{-1}$ $\left(\mathrm{T}_{5}\right)$ and Metsulfuron methyl 20\% WP @ $0.004 \mathrm{~kg}$ a.i. $\mathrm{ha}^{-1}\left(\mathrm{~T}_{6}\right)$.

In between all the given the treatments, maximum DMA of weeds was recorded under the unweeded control treatment $(2.00,13.21$ and $20.21 \mathrm{gm} \mathrm{m}^{-2}$ respectively) at all the observations. This was in close conformity with the findings of Biswas et al., 2017.

The weed control efficiency derived from the weed dry weight revealed, hand weeding twice $\left(\mathrm{T}_{7}\right)$ resulted with the higher weed control efficiency of 51.50, 35.88 and 44.24 $\%$ during 20, 40 and 60 DAS respectively that's already shown in table 2. This was followed by 2,4-D amine 50\% SL (Nufarm) @ $1.0 \mathrm{~kg}$ a.i. $\mathrm{ha}^{-1}\left(\mathrm{~T}_{4}\right)(40.00,16.73$ and 34.34 $\%$ at 20,40 and 60 DAS respectively) and 2,4-D amine 50\% SL (Nufarm) @ $0.75 \mathrm{~kg}$ a.i. $\mathrm{ha}^{-1}\left(\mathrm{~T}_{3}\right)(40.00,15.82$ and $32.06 \%$ at 20,40 and 60 DAS respectively).

The weed control efficiency of the aforesaid treatments remained comparable with each other and better than other treatments. The lowest WCE was recorded in unweeded control plot $\left(\mathrm{T}_{8}\right)$. Similar type of results was also observed by the application of 2,4-D to reduce weed dry weight and WCE in irrigated wheat (Singh et al., 2013).

\section{Effect on crop}

\section{Phytotoxicity}

The observation on visual crop toxicity was done on 7, 14 and 21 days after herbicide application (DAHA). The visual crop toxicity symptoms like leaf injury, vein clearing, epinasty, hyponasty, scorching and necrosis were observed. There were no crop Phytotoxicity symptoms among the different treatments as well as at the highest dose of 2,4-D amine 50\% SL (Nufarm) @ $2.00 \mathrm{~kg}$ a.i. $\mathrm{ha}^{-1}\left(\mathrm{~T}_{9}\right)$ shown in table 3 and also indicated that the herbicide was safe for wheat.

\section{Grain yield and Weed Index [WI]}

From the table 3, it has been observed thatHand weeding twice $\left(\mathrm{T}_{7}\right)$ recorded the highest grain yield of $1.85 \mathrm{tha}^{-1}$ which was on par with2,4-D amine 50\% SL (Nufarm) @ $1.00 \mathrm{~kg}$ a.i. ha ${ }^{-1}\left(\mathrm{~T}_{4}\right)\left(1.80 \mathrm{t} \mathrm{ha}^{-1}\right)$. This was followed by 2,4-D amine 50\% SL (Nufarm) @ $0.75 \mathrm{~kg}$ a.i. ha ${ }^{-1}\left(\mathrm{~T}_{3}\right)\left(1.70 \mathrm{tha}^{-1}\right)$ and 2,4-D amine 50\% SL (Nufarm) @ 0.50 kg a.i. ha ${ }^{-1}$ $\left(\mathrm{T}_{3}\right)\left(1.61 \mathrm{tha}^{-1}\right)$ respectively.

On the basis of recorded data presented in table 3, its clearly reveal that except hand weeding twice $\left(T_{7}\right)$ treatment, the lowest weed index which was shown in 2,4-D amine $50 \%$ SL (Nufarm) @ $1.00 \mathrm{~kg}$ a.i. ha ${ }^{-1}\left(\mathrm{~T}_{4}\right)$ (2.70\%) that's followed by 2,4-D amine $50 \%$ SL (Nufarm) @ $0.75 \mathrm{~kg}$ a.i.ha ${ }^{-1}\left(\mathrm{~T}_{3}\right)(8.10 \%)$. Lower weed index indicated lesser grain yield reduction due to minimum crop-weed competition period suggested by Raj et al., 2013.

From the above study, it can be concluded that 2,4-D amine 50\% SL (Nufarm) @ 1.00 $\mathrm{kg}$ a.i. $\mathrm{ha}^{-1}\left(\mathrm{~T}_{4}\right)$ and 2,4-D amine 50\% SL 
(Nufarm)@ $0.75 \mathrm{~kg}$ a.i. ha ${ }^{-1}\left(\mathrm{~T}_{3}\right)$ was most effective to check all type of weed population and also resulted better wheat grain yield which may be recommended to the farmer of gangetic alluvial zone, West Bengal for remunerative growth and development of rabi season wheat.

2,4-D amine 50\% SL tested at different doses for Phytotoxicity has revealed that there is no Phytotoxicity symptoms observed in any of the doses and the tested new formulation is safe to the wheat crop in the agro-zones of West Bengal including the country as a whole.

\section{Acknowledgement}

The authors would like to thanks M/S. Mahamaya Life sciences Pvt. Ltd., Gurgaon for providing the Technical grade i.e. 2,4-D amine $50 \%$ SL and also for financial assistance for coordinating the research activities.

\section{References}

Agricultural Statistics at a Glance. 2016. Government of India, Ministry of Agriculture, Department of Agriculture and Co-operation, Directorate of Economics \& Statistics, New Delhi. pp. 90-92.

Baghestani, M.A., Zand, E., Soufizadeh, S., Bagherani, N. and Deihimfard, R. (2007). Weed control and wheat (Triticum aestivum L.) yield under application of 2,4-D plus carfentrazoneethyl and florasulam plus flumetsulamEvaluation of the efficacy. Crop Protect. 26:1759-1764.

Bandyopadhyay, S., Kundu, C.K., Kundu, A., Bandyopadhyay, P.K., Banerjee, S. and Bera, P.S. (2017). Studies on bioefficacy and phytotoxicity of 2,4-d ethyl hexyl ester $60 \%$ EC in wheat under
Gangetic Alluvial Zone of West Bengal. Journal of Crop and Weed, 13(1): 192195.

Begum, M., Iqbal, M.Z., Karim, R.S.M. and Mamun, A.A. 2003. Weed flora of wheat, mustard and lentil grown in old Brahmaputra flood plain soils of Bangladesh. Bangladesh Journal of Agricultural Science 30: 129-134.

Biswas, U., Kundu, A., Labar, A., Datta, M.K. and Kundu, C.K. 2017. Bioefficacy and Phytotoxicity of 2,4-D Dimethyl Amine 50\% SL for Weed Control in Potato and Its Effect on Succeeding Crop Greengram. Int.J. Curr.Microbiol.App.Sci. 6(11): 12611267.

Buczek, J., Szpunar-Krok, E., BobreckaJamro, D. 2011. Yield and weed infestation of winter wheat in dependence on sowing density and agricultural practice level. Acta Scientiarum Polonorum. Agricultura 10.

Chhokar, R.S., Sharma, R.K, Chauhan, D.S. and Mongia, A.D. 2006. Evaluation of herbicides against Phalaris minor in wheat in north-western Indian plains. Eur. Weed Res.46:40-49.

Das, T. K. 2013. Weed science basics andapplications. Jain Brothers. New Delhi, pp. 381.

Dickson, J.W., Scott, R.C., Burgos, N.R., Salas, R.A. and Smith, K.L. 2011. Confirmation of glyphosateresistant Italian ryegrass (Loliumperenne ssp. multiflorum) in Arkansas. Weed Technology 25: 674-679.

Duke, S. and Lydon, O. 1987. Herbicides from natural compounds. Weed Technol. 1:122-128.

Fisher, R A. 1958. Statistical Methods for Research workers. Oliver \& Boyd, Edinburg, London.

Gella, D., Ashagre, H. and Negewo, T. 2013. Allelopathic effect of aqueous extracts 
of major weed. Journal of Agricultural Crop Research 1: 30-35.

Heyne, E.G. 1987. Wheat and Wheat in Improvement. $2^{\text {nd }}$ Edition, Madison, Wisconsin.

Ito, D., Miller, Z., Menalled, F., Moffet, M. and Burrows, M. 2012. Relative susceptibility among alternative host species prevalent in the Great Plains to wheat streak mosaic virus. Plant Disease 96: 1185-1192.

Jarwar, A.D., Tunio, S.D., Majeedano, H.I. and Kaisrani, M.A. 1999. Efficacy of different weedicides in controlling weeds of wheat. Pak. J. Agric. Eng. Vet. Sci. 15: 17-20.

Javaid, A., Bajwa, R., Rabbani, N. and Anjum, T. 2007. Comparative tolerance of six rice (Oryza sativa L.) genotypes to allelopathy of purple nutsedge (Cyperus rotundus L.). Allelopathy Journal 20: 157-166.

Kundu, A., Kundu, C.K., Hedayetullah, M.D., Datta, M.K., Bairagya, M.D. and Das, U. 2018. Performance of 2,4-D Dimethyl amine $50 \%$ SL on weed control of Non-crop area under New Alluvial Zone of West Bengal. Journal of Pharmacognosy and Phytochemistry, 7(1): 1187-1190.

Kundu, A., Kundu, C.K., Khan, R., Roy, S.S., Majumder, A., Mukherjee, D. and Lamana, M.C.L. 2017. Effect of 2,4-D Ethyl Ester $80 \%$ EC on weed control in wheat. Journalof Crop and Weed, 13(1): 203-205.

Lopez-Granados, F. 2011. Weed detection for site specific weed management: mapping and real-time approaches. Weed Research 51: 1-11.

Marwat, K.B., Khan, M.A., Hashim, S., Nawab, K. and Khattak, A.M. 2011. Integrated weed management in wheat. Pakistan Journal of Botany 43: 625-633.
Njoroge, J.M. 1999. 17 East African Biennial Weed Science Conference Proceedings, 65-71.

Noorka, I.R. and Teixeira da Silva, J.A. 2012. Mechanistic Insight of Water Stress Induced Aggregation in Wheat (Triticum aestivum L.) Quality: The Protein Paradigm Shift. Notulae Scientia Biologicae, 4: 32-38.

Pandey J. and Singh R. 1997. Weed control in wheat is key to higher production. Indian farming, 47 (8): 4-7.

Postic, J., Cosic, J., Vrandecic, K., Jurkovic, D., Saleh, A.A. and Leslie, J.F. 2012. Diversity of Fusarium Species Isolated from Weeds and Plant Debris in Croatia. Journal of Phytopathology. 160: 76-81.

Qureshi, R. and Bhatti, G.R. 2001. Determination of weed communities in wheat (Triticum aestivum L.) fields of district Sukkur. Pakistan Journal of Botany. 33: 109-115.

Raj, S.K., Jose, Mathew R. and Leena Kumary, S. 2013. Chemical management of non-grassy weeds in direct-seeded rice. Indian J. Weed Sci, 45:159-62.

Rao, V.S. 2000. Principles of weed science (2nd Ed.). Oxford and IBH Publishing Co. Pvt. Ltd. New Delhi, India.

Rathore, M., Singh, R., Choudhary, P.P. and Kumar, B. 2014. Weed Stress in Plants. In: Approaches to Plant Stress and their Management. Springer India. India, 255-265.

Reddy, T.Y. and Reddi, G.H.S. 2002. Weed management, In. Principles of Agronomy, Kalyani Publishers, New Delhi, India, 418.

Shehzad, M.A., Maqsood, M., Anwar-ul-Haq, M. and Niazm, A. 2012. Efficacy of various herbicides against weeds in wheat (Triticum aestivum L.). African. Journal of Biotechnology 11: 791-799. 
Singh, R.K., Singh, D.K. and Singh, R.P. 1997. Weed crop competition in wheat as affected by different weed species. Indian Journal of Weed Science 29: 6971.

Singh, R.K., Singh, S.R.K and Gautam, U.S. 2013. Weed Control Efficiency of Herbicides in Irrigated Wheat (Triticum aestivum). Indian Res. J. Ext. Edu. 13(1): 126-128.

Singh, R.K., Singh, S.R.K. and Gautam, U.S. 2013. Weed Control Efficiency of Herbicides in Irrigated Wheat (Triticum aestivum). Indian Res. J. Ext. Edu. 13 (1): 126-128.

Wilson, R.D., Geronimo, J and Armbruster, A. 1997. 2, 4-D Dissipation in Field Soils after Applications of 2, 4-D Dimethylamine Salt and 2, 4-D 2-Ethyl Hexyl Ester. Environmental Toxicology and Chemistry, 16(6): 1239-1246.

Zand, E., Baghestani, M.A., Soufizadeh, S., Eskandari, A., Pour Azar, R. and Veysi, M. 2007. Evaluation of some newly registered herbicides for weed control in wheat (Triticum aestivum L.) in Iran. Crop Protect. 26: 1349-1358.

\section{How to cite this article:}

Arindam Kundu, Champak Kumar Kundu, Himangshu Das, Kanu Murmu and Kalyan Jana. 2018. Studies on 2,4-D Dimethylamine 50\% SL to Control Weeds in Wheat. Int.J.Curr.Microbiol.App.Sci. 7(09): 335-344. doi: https://doi.org/10.20546/ijcmas.2018.709.041 